\title{
Attention Deficit Hyperactivity Disorder among Clients Diagnosed with a Substance Use Disorder in the Therapeutic Communities: Prevalence and Psychiatric Comorbidity
}

\author{
Michal Miovský Kateřina Lukavská Eva Rubášová Lenka Štastná \\ Martin Šefránek Roman Gabrhelík
}

Department of Addictology, First Faculty of Medicine, Charles University and General University Hospital in Prague,

Prague, Czech Republic

\section{Keywords \\ Epidemiology - Diagnosis - Attention deficit hyperactivity disorder - Treatment of addictions - Therapeutic community . Comorbidity - Substance use disorder - Methamphetamine . Psychiatric symptoms $\cdot$ Mental health}

\begin{abstract}
Background: Most severe substance use disorders (SUDs) are connected with attention deficit hyperactivity disorder (ADHD) and other mental health problems. Therapeutic communities (TCs) provide a suitable option for the treatment of severe SUDs. The relationship between ADHD, the severity of the SUD, and other comorbidities in residential TCs is unknown. Objective: To estimate the prevalence of ADHD among clients with an SUD in residential rehab, and to compare the mental health of clients with and without ADHD. Methods: A cohort study was conducted in 5 residential TCs $(N=180,76.7 \%$ male, $53.9 \% 25-34$ years, $79.2 \%$ diagnosed with methamphetamine use disorder). We assessed ADHD symptoms, substance use, mental health problems, and psychiatric symptoms. Results: ADHD was found in 51\% of the clients who showed significantly higher scores for their psychiatric status composite score (ASI-PSY) $(F=9.08$,
\end{abstract}

$p<0.001 ; t=5.05, p<0.001)$, the positive psychiatric symptoms total (SCL-PST) $(F=3.36, p<0.05 ; t=3.15, p<0.01)$, and the global severity index (SCL-GSI) $(F=3.27, p<0.05 ; t=3.18$, $p<0.01)$. The ASI-PSY and SCL correlated significantly with the symptoms of attention deficit disorder (Pearson's r's = $\left.0.30-0.42, p^{\prime} s<0.001\right)$ and the symptoms of hyperactivity disorder ( $r$ 's $=0.24-0.30, p^{\prime} s<0.01$ ). Even when severity of substance use was accounted for, ADHD was confirmed as a significant predictor of ASI-PSY ( $B=0.14, p<0.001$ for combined disorder; $B=0.20, p<0.001$ for attention disorder) and partially of SCL-PST ( $B=8.12, p<0.05$ for attention disorder). Conclusions: The ADHD prevalence in TCs was nearly 10fold compared to the globally recorded values. ADHD diagnostic procedures and interventions should become an integral part of the standard diagnostic and treatment process.

(c) 2020 The Author(s)
Published by S. Karger AG, Basel

\section{Introduction}

Attention deficit hyperactivity disorder (ADHD) is a substantial mental health comorbidity in substance users [1]. The overall prevalence of ADHD has been estimated at $3.4 \%$ in the adult population [2] and $7.2 \%$ for those
(C) 2020 The Author(s)

Published by S. Karger AG, Basel

This is an Open Access article licensed under the Creative Commons Attribution-NonCommercial-4.0 International License (CC BY-NC) (http://www.karger.com/Services/OpenAccessLicense), applicable to the online version of the article only. Usage and distribution for commercial purposes requires written permission.
Michal Miovský

Department of Addictology, First Faculty of Medicine

Charles University and General University Hospital in Prague

Apolinářská 4, Prague CZ-12000 (Czech Republic)

michal.miovsky@lf1.cuni.cz 
aged up to 18 years [3]. In the population of substance users, the prevalence of ADHD, according to a meta-analysis, has been estimated at $23.1 \%$ (21\% in adults and $25.3 \%$ in adolescents) [4]. The prevalence estimates may differ according to the type of substance used and the subpopulations or treatment modality. For example, the following populations of patients in opioid maintenance treatment (OMT) were screened positively for ADHD: in Norway, $33 \%$ of OMT patients [5], in Austria, in 50\% of children and $17 \%$ of adults of the mainly male prison inmates in OMT [6], and in Italy, $11.2 \%$ of OMT patients [7]. In the methamphetamine-using population of one hospital's psychiatric center, the prevalence of the ADHD diagnosis went up to $55.6 \%$ [8]. In a feasibility study conducted in therapeutic communities (TCs) in the Czech Republic, the prevalence of ADHD reached 56.6\% [9]. However, both studies have methodological limitations.

ADHD can contribute to the development and persistence of substance use disorders (SUDs) $[10,11]$. Kalbag and Levin [12] described ADHD as a factor which complicates the therapeutic process. In addition to ADHD itself, the treatment process may be complicated by other mental health problems which are frequently reported in relation to $\mathrm{ADHD}$, for example, personality disorders [1, 13-15] or specific learning disorders [16]. Arias et al. [17] found more severe SUDs in ADHD patients in connection with repeated hospitalization as a result of the associated comorbidity.

TCs provide a suitable option for the treatment of severe SUDs [18-20], including methamphetamine dependence, in a relatively homogenous setting [21]. TCs are the treatment of choice for those who have had repeated treatment attempts and have a complicated addiction profile that is often accompanied by other comorbid conditions which do not require intensive medical attention. TC residents with ADHD showed higher rates of treatment-related complications (early drop-out, psychological problems, psychiatric comorbidity, psychopharmacotherapy, and behavioral and cognitive deficits) $[9,22]$. Currently, the number of research studies conducted in TCs is limited, current evidence is scarce, there are indications of a huge insufficiency in communication between the science and the practice [23], and clinical research conducted in TCs which has publishable and respectable scientific results is lacking [21]. Therefore, we decided to conduct a study on the relationship between ADHD, the severity of SUDs, and other comorbidities in residential TCs.

The aim of the study was to assess the prevalence of ADHD among clients in residential TCs for addiction treatment. Furthermore, we compared the frequency and severity of mental health problems between clients screened ADHD positive and those without ADHD.

\section{Materials and Methods}

\section{Setting}

Residential TCs are an integral part of the treatment services for substance users; $78 \%$ of the clients in TCs were users of methamphetamine as a primary drug in 2016 [24]. In total, 15 residential TCs provided addiction treatment, 10 of which TCs were certified, that is, they provided treatment according to the Czech professional standards and internationally recognized treatment models and methods $[19,24]$. Clients of Czech TCs do not constitute a large population. Combined, all certified TCs provide treatment to $\sim 300$ clients per year $[25,26]$.

\section{Data Collection}

The data were collected between June 2014 and December 2015 (18 months). All 10 certified Czech TCs were asked to participate in the study. Seven TCs agreed to participate, but 2 of them failed to start the data collection and so were excluded from the study. Out of the total number of 271 patients entering treatment in the 7 participating TCs during the study period, 242 patients agreed to participate and start data collection. Fifty participants were excluded as their TC ceased its participation, and 12 more were excluded from the dataset because of the large number of missing values (66.69-100\% in variables of interest; see below). The study sample consisted of 180 clients from 5 TCs, which means that the response rate was $66.4 \%$. No significant differences were found between the excluded participants and the final sample in the areas of education, marital status, residence, duration of previous therapy, dominant drug distribution, ADHD distribution (the ratio of those who screened positive), and the severity of psychiatric symptoms (as measured by SCL-GSI). However, we found that the excluded participants were significantly younger $(M=24.2, \mathrm{SD}=5.61$, $t[55.2]=-3.84, p<0.001)$ and had a smaller proportion of men $\left(47.6 \%, \chi^{2}[1]=14.0, p<0.001, N=222\right)$ when compared to the final sample. It should be noted that we did not have all of the data from all the excluded participants. All of the participants were assessed within the first 10 days of the initiation of treatment [27]. The data were collected by professionals who were trained in test battery administration and were supervised by 3 research co-ordinators. Substance use-related diagnoses were coded according to the International Statistical Classification of Diseases, 10th Revision (ICD-10).

\section{Outcome Measures}

Standard sociodemographic characteristics were obtained (Table 1).

\section{ADHD Measurement}

For the assessment of ADHD, we used the DIVA 2.0 inventory [28], which is a comprehensive self-report scale for $\mathrm{ADHD}$ screening according to the DSM-5 criteria. It contains the manifestations for the 9 core symptoms of attention disorder and hyperactive disorder that are typical in either adulthood or childhood. A positive screening requires the presence of at least 6 of
88

Eur Addict Res 2021;27:87-96 DOI: $10.1159 / 000508571$
Miovský/Lukavská/Rubášová/Štastná/ Šefránek/Gabrhelík 
Table 1. Sociodemographic characteristics of the sample $(N=180)$

\begin{tabular}{|c|c|c|}
\hline & $N$ & Percentage \\
\hline \multicolumn{3}{|l|}{ Gender } \\
\hline Male & 138 & 76.70 \\
\hline Female & 42 & 23.30 \\
\hline \multicolumn{3}{|l|}{ Age* $^{*}$} \\
\hline $15-24$ years old & 56 & 31.11 \\
\hline $25-34$ years old & 97 & 53.88 \\
\hline$>35$ years old & 26 & 14.44 \\
\hline Missing & 1 & 0.56 \\
\hline \multicolumn{3}{|l|}{ Education ${ }^{* *}$} \\
\hline Elementary (9) & 72 & 40.00 \\
\hline Practical (12) & 61 & 33.90 \\
\hline Practical with graduation (13) & 4 & 2.20 \\
\hline High school with graduation (13) & 31 & 17.20 \\
\hline Uncompleted further education & 12 & 6.70 \\
\hline \multicolumn{3}{|l|}{ Marital status } \\
\hline Single & 162 & 90.00 \\
\hline Married & 3 & 1.66 \\
\hline In partnership & 3 & 1.66 \\
\hline Divorced & 11 & 6.11 \\
\hline Missing & 1 & 0.56 \\
\hline \multicolumn{3}{|l|}{ Residence } \\
\hline Large city (>100,000 inhabitants) & 51 & 28.33 \\
\hline Medium-sized town $(10,000-100,000$ inh.) & 70 & 38.89 \\
\hline Small town/country ( $<10,000$ inh. $)$ & 40 & 22.22 \\
\hline Missing & 19 & 10.56 \\
\hline \multicolumn{3}{|l|}{ Previous therapy } \\
\hline$<6$ months & 97 & 53.89 \\
\hline $6-12$ months & 36 & 20.00 \\
\hline $12-18$ months & 12 & 6.67 \\
\hline$>18$ months & 8 & 4.44 \\
\hline Missing & 27 & 15 \\
\hline
\end{tabular}

* Age ranged from 17 to 50 (mean $=28.1$, SD 6.11, median $=$ 28.0). ${ }^{* *}$ The usual number of years spent in education to reach the level that appears in parentheses next to the educational level.

the symptoms, which must be present from childhood. DIVA 2.0 distinguished the 4 groups of (1) participants with a combined disorder who reported 6 or more symptoms for both attention disorder and hyperactivity disorder which were present from childhood, (2) participants with attention disorder who reported 6 or more symptoms of attention disorder which were present from childhood, (3) participants with hyperactivity disorder who reported 6 or more symptoms of hyperactivity which were present from childhood, and (4) non-ADHD participants who reported $<6$ symptoms in either the attention disorder or the hyperactivity disorder part. Since these are nonparametric measures, we also used 2 parametric measures - attention deficit disorder symptoms and hyperactivity disorder symptoms, calculated as a sum of the positive symptoms in each section. Both DIVA scales demonstrated very good internal consistency in our sample. The Attention scale showed Cronbach's $\alpha=0.920$ with item-rest correlations ranging from 0.50 to 0.66 , and the Hyper-

ADHD in the Therapeutic Community
Table 2. Substance use characteristics of the sample $(N=180)$

\begin{tabular}{lrrrr}
\hline \multirow{2}{*}{ Substance } & \multirow{2}{*}{ Users* } & \multicolumn{4}{l}{ Usage in years } \\
\cline { 3 - 5 } & $N$ & mean & median & \multicolumn{1}{l}{ SD } \\
\hline Alcohol use & 158 & 11.60 & 12.00 & 6.61 \\
Alcohol heavy use & 91 & 6.27 & 4.00 & 6.10 \\
Heroin & 38 & 4.85 & 3.00 & 4.82 \\
Opioids & 33 & 4.70 & 2.00 & 4.89 \\
Depressants & 45 & 4.83 & 3.00 & 4.67 \\
Methamphetamine & 166 & 9.04 & 9.00 & 5.05 \\
Cocaine & 33 & 2.10 & 2.00 & 1.63 \\
Amphetamine & 75 & 4.96 & 4.00 & 3.94 \\
Cannabis & 162 & 9.46 & 8.50 & 5.56 \\
Hallucinogens & 78 & 5.32 & 5.00 & 4.53 \\
Inhalants & 21 & 2.95 & 1.00 & 3.96 \\
Combination & 98 & 8.42 & 8.00 & 5.46 \\
Overdose & 89 & - & - & - \\
Substance count & - & 3.65 & 3.00 & 1.91 \\
Substance use total & - & 25.10 & 21.00 & 17.80 \\
\hline
\end{tabular}

* A person using the substance regularly for at least 6 months was categorized as a user.

activity scale showed Cronbach's $\alpha=0.917$ with item-rest correlations ranging from 0.39 to 0.70 .

\section{Psychiatric Symptoms}

Two scales were used to assess the psychiatric symptoms: (1) EuropASI [29] - Psychiatric status (part I), which consisted of 23 items. The participants were asked to indicate whether, in the past 30 days, they had experienced mental health problems such as serious depression, anxiety, cognitive deficit, hallucinations, self-control deficit, suicidal thoughts, or suicide attempt(s) and whether they had had psychiatric medication. (2) Symptoms Checklist 90 (SCL-90) $[30,31]$ consists of 90 items divided into 9 sections measuring the respondent's symptoms of somatization, obsession-compulsion, interpersonal sensitivity, depression, anxiety, hostility, phobic anxiety, paranoid ideation, and psychoticism.

We used 2 different scales to measure mental health - EuropASI and SCL-90 - because both methods have their merits. EuropASI showed good predictive validity for the additional psychiatric treatment of SUD patients [32]. SCL-90 was developed for a more general use and thus enables comparisons across different populations.

To assess the psychiatric symptoms, 3 scores were computed: (1) the EuropASI composite score for psychiatric status (ASI-PSY) using the standard procedure for the computation of EuropASI composite scores [33]; (2) the psychiatric symptoms total (SCLPST) as a sum of individual psychiatric symptoms (0-90), and (3) the global severity index (SCL-GSI) as the average value of all symptoms, indicating the severity of symptoms (with the severity of each symptom measured on a scale from 0 to 4 ).

\section{Substance Use Severity}

The severity of the participants' substance use was assessed using the European Addiction Severity Index (EuropASI [29]) - the 
Table 3. Mental health problem means for the whole sample and ADHD groups

\begin{tabular}{|c|c|c|c|c|c|c|}
\hline \multirow[t]{2}{*}{ Variable $(N)$} & \multirow{2}{*}{$\begin{array}{l}\text { Whole sample } \\
N=180\end{array}$} & \multicolumn{5}{|l|}{ ADHD group } \\
\hline & & $\begin{array}{l}\text { combined } \\
N=39(21.7 \%)\end{array}$ & $\begin{array}{l}\text { attention } \\
N=38(21.1 \%)\end{array}$ & $\begin{array}{l}\text { hyperactive } \\
N=14(7.8 \%)\end{array}$ & $\begin{array}{l}\text { none } \\
N=89(49.4 \%)\end{array}$ & $F$ \\
\hline ASI-PSY (176) & $0.28(0.22)$ & $0.34(0.21)$ & $0.39(0.22)$ & $0.30(0.23)$ & $0.20(0.19)$ & $9.08^{* * *}$ \\
\hline SCL-PST (180) & $53.1(19.6)$ & $56.4(16.2)$ & $57.7(18.6)$ & $60.2(16.8)$ & $48.6(20.9)$ & $3.36^{*}$ \\
\hline SCL-GSI (180) & $1.18(0.68)$ & $1.33(0.62)$ & $1.35(0.73)$ & $1.28(0.64)$ & $1.02(0.67)$ & $3.27^{*}$ \\
\hline Interpersonal sensitivity (180) & $1.44(0.91)$ & $1.65(0.87)$ & $1.71(0.98)$ & $1.53(0.84)$ & $1.23(0.87)$ & $3.48^{*}$ \\
\hline Depression (180) & $1.36(0.85)$ & $1.46(0.84)$ & $1.60(0.84)$ & $1.31(0.64)$ & $1.22(0.87)$ & $2.01^{*}$ \\
\hline Anxiety (180) & $1.25(0.79)$ & $1.49(0.70)$ & $1.43(0.86)$ & $1.37(0.61)$ & $1.05(0.78)$ & 4.16 \\
\hline Hostility (180) & $1.12(0.86)$ & $1.36(0.84)$ & $1.28(0.85)$ & $1.55(1.00)$ & $0.88(0.79)$ & $4.94^{* *}$ \\
\hline SCL-phobic anxiety (180) & $0.73(0.70)$ & $0.72(0.64)$ & $0.90(0.86)$ & $0.94(0.67)$ & $0.62(0.64)$ & 1.69 \\
\hline
\end{tabular}

Date are presented as means (SD). ADHD, attention deficit hyperactivity disorder; ASI-PSY, EuropASI composite score for psychiatric status; SCL-PST, psychiatric symptoms total; SCL-GSI, global severity index. ${ }^{*} p<0.05 .{ }^{* *} p<0.01 .{ }^{* * *} p<0.001$.

Drug Anamnesis part. We measured 4 variables: (a) The presence of polydrug use (simultaneous use of at least 2 different substances) - question "Have you been using at least 2 different substances in the same day?" (b) The history of overdose - question "How many times have you overdosed?" (c) The cumulative substance use in years - the sum of answers to question "For how many years have you been using heroin?," "For how many years have you been using cannabis?," "For how many years have you been using methamphetamine?," etc. (d) The number of different substances that the participant had used for at least 6 months. The full list of substances is shown in Table 2.

\section{Analysis Strategy and Statistics}

Initially, we divided the sample into ADHD groups based on DIVA 2.0 and assessed the prevalence. The means and standard deviations of ASI-PSY, SCL-PST, and SCL-GSI were computed for each ADHD group. Between-groups differences were analyzed by mean comparison methods. Correlation analyses were computed to further investigate the links between attention deficit and hyperactivity disorder symptoms and mental health.

Finally, we used regressive modeling to further examine the effects of ADHD on ASI-PSY (model 1) and SCL-PST (model 2). In both models, the ADHD group (combined, attention, and hyperactivity) was tested as a predictor, along with variables indicating the severity of substance use. The data were analyzed with the statistical program $\mathrm{R}$ [34].

\section{Missing Data}

The variables of interest (DIVA, SCL-90, EuropASI Psychiatric status items) were analyzed for missing data. We found that the ratio of missing values ranged from $0 \%$ (DIVA) to $2.32 \%$ (EuropASI Psychiatric status). The overall ratio of missing values was $0.38 \%$. Most participants $(n=169)$ had no missing values. In the case of EuropASI Psychiatric status, we found 4 participants with a high percentage of missing values (73-100\%) and decided not to use their data in relevant analyses. In participants with $<20 \%$ of missing values per test, the multiple imputation (Amelia II software by Honaker et al. [35]) was used to replace the missing data $[36,37]$. The number of imputed values was very small: $0 \%$ in the case of DIVA, $0.3 \%$ in the case of SCL- 90 , and $0.3 \%$ in the case of EuropASI Psychiatric status.

\section{Ethics}

The study was approved by the Institutional Review Board of the General University Hospital in Prague (9/2013 Grant GACR 1. LF UK). Informed consent was obtained in written form from all participants.

\section{Results}

\section{Sample Characteristics}

The sociodemographic characteristics of the sample are shown in Table 1. We observed very high sociodemographic homogeneity in the sample. There was a distinctive majority of young, single men with elementary or vocational education. The majority of the participants had a history of previous SUD treatment shorter than 6 months at the time of the data collection.

\section{Substance Use}

Homogeneity was also found in the clients' drug use history. The dominant drug problem which motivated clients to enter the TC was mostly methamphetamine
90
Eur Addict Res 2021;27:87-96 DOI: $10.1159 / 000508571$
Miovský/Lukavská/Rubášová/Štastná/ Šefránek/Gabrhelík 
Table 4. Pearson's correlations between mental health problems and $\mathrm{ADHD}$ symptoms $(N=180)$

\begin{tabular}{lll}
\hline & $\begin{array}{l}\text { Attention deficit } \\
\text { disorder } \\
\text { symptoms }\end{array}$ & $\begin{array}{l}\text { Hyperactivity } \\
\text { disorder } \\
\text { symptoms }\end{array}$ \\
\hline ASI-PSY & $0.42^{* * *}$ & $0.30^{* * *}$ \\
SCL-PST & $0.31^{* * *}$ & $0.24^{* *}$ \\
SCL-GSI & $0.30^{* * *}$ & $0.25^{* * *}$ \\
Somatization & $0.21^{* *}$ & $0.16^{*}$ \\
Obsessive-compulsive & $0.35^{* * *}$ & $0.30^{* * *}$ \\
Interpersonal sensitivity & $0.32^{* * *}$ & $0.22^{* *}$ \\
Depression & $0.25^{* * *}$ & 0.14 \\
Anxiety & $0.30^{* * *}$ & $0.27^{* * *}$ \\
Hostility & $0.30^{* * *}$ & $0.31^{* * *}$ \\
Phobic anxiety & $0.22^{* *}$ & $0.17^{*}$ \\
Paranoid ideation & $0.21^{* *}$ & $0.23^{* *}$ \\
Psychoticism & $0.20^{* *}$ & $0.22^{* *}$ \\
\hline
\end{tabular}

ADHD, attention deficit hyperactivity disorder; ASI-PSY, EuropASI composite score for psychiatric status; SCL-PST, psychiatric symptoms total; SCL-GSI, global severity index. ${ }^{*} p<$ 0.05. ${ }^{* *} p<0.01$. ${ }^{* * *} p<0.001$.

(141 participants, $79.2 \%)$, followed by cannabis (7.9\%), opioids (5\%), and alcohol (4.5\%). Other substances were reported as a dominant drug problem in $<2 \%$ of the patients. Table 2 shows the number of users of each substance, the average duration of the substance use in years, and the substance use severity measures.

\section{ADHD Prevalence}

Table 3 shows the prevalence of ADHD in the sample. ADHD was indicated in $50.6 \%$ of the sample. The most common were combined disorder $(21.7 \%)$ and attention deficit disorder (21.1\%). A minority of the participants showed symptoms of hyperactivity disorder (7.8\%).

\section{Mental Health Problems in ADHD and Non-ADHD Participants}

The scores for mental health problems were lowest in the non-ADHD group. The between-groups differences were statistically significant for all the composite scores and for some symptoms (namely, obsessive-compulsive, interpersonal sensitivity, anxiety, and hostility) (Table 3). Post hoc tests (Games-Howell) showed significant differences in ASI-PSY between the combined ADHD and non-ADHD participants $(\mathrm{MD}=0.14, t[68.3]=3.57, p=$ $0.004)$ and attention disorder and non-ADHD participants $(\mathrm{MD}=0.19, t[62.1]=4.69, p<0.001)$. For the SCL variables, post hoc tests were significant for differences between combined ADHD and non-ADHD in cases of obsessive-compulsive symptoms $(\mathrm{MD}=0.48, t[78.8]=$ $3.77, p=0.002)$, anxiety $(\mathrm{MD}=0.44, t[79.8]=3.19, p=$ $0.011)$, and hostility $(\mathrm{MD}=0.48, t[69.0]=3.05, p=0.017)$. Finally, there was a significant difference in the interpersonal sensitivity between participants with attention disorder and non-ADHD participants $(\mathrm{MD}=0.49, t$ $[62.8]=2.65, p=0.048$ ).

The merged group of ADHD participants (consisting of participants with combined, attention, and hyperactivity disorders) showed significantly higher scores for ASIPSY $(\mathrm{MD}=0.157$, Welch's $t[173]=5.07, p<0.001$, Cohen's $d=0.76)$, SCL-PST (MD $=8.98, t[170]=3.15, p=$ $0.002, d=0.47)$ and SCL-GSI $(\mathrm{MD}=0.315, t[178]=3.18$, $p=0.002, d=0.47$ ) and for all the categories of symptoms, excluding somatization. The most pronounced were the differences between ADHD-positive and ADHD-negative participants in obsessive-compulsive $(\mathrm{MD}=0.41$, $t[178]=3.90, p<0.001, d=0.58)$, anxiety $(\mathrm{MD}=0.40$, $t[178]=3.50, p<0.001, d=0.52)$, and hostility (MD = $0.48, t[177]=3.87, p<0.001, d=0.58)$. Furthermore, we found small to medium correlations between the mental health problems and the attention and hyperactivity symptoms (Table 4).

Finally, ADHD (specifically combined disorder and attention disorder) was found to be a statistically significant predictor of ASI-PSY, which was alone able to account for $\sim 14 \%$ of its variance (Table 5). Surprisingly, the variables indicating the severity of substance use were not significant predictors and only improved the overall explanatory power of the model by $1.2 \%$ (Table 5).

The relationships between the ASI-PSY and SCL scores were statistically significant $(p<0.001)$ and moderately strong (Pearson's $r$ was 0.35 between ASI-PSY and SCLPST and 0.43 between ASI-PSY and SCL-GSI). ADHD was also partially able to predict SCL-PST; however, only attention disorder proved to be a statistically significant predictor, and the overall explanatory power of the model was weak - about $5 \%$ of the variance (Table 6 ).

\section{Discussion}

Our study confirmed the strong link between methamphetamine use and ADHD, and also between ADHD and mental health problems. More than $79 \%$ of those in the study sample were primarily methamphetamine users. More than half of the sample of TC clients were $\mathrm{ADHD}$ positive. ADHD-positive clients showed a more 
Table 5. Summary of hierarchical regression analysis for variables predicting psychiatric status (ASI-PSY) $(N=176)$

\begin{tabular}{|c|c|c|c|c|c|c|}
\hline \multirow[t]{2}{*}{ Variable } & \multicolumn{3}{|c|}{ Model 1a } & \multicolumn{3}{|c|}{ Model 1b } \\
\hline & $B$ & SE & $t$ & $B$ & SE & $t$ \\
\hline \multicolumn{7}{|l|}{ ADHD group } \\
\hline Combined-none & 0.142 & 0.040 & $3.57^{* * *}$ & 0.143 & 0.042 & $3.396^{* * *}$ \\
\hline Attention-none & 0.194 & 0.059 & $4.80^{* * *}$ & 0.197 & 0.041 & $4.785^{* * *}$ \\
\hline Hyperactivity-none & 0.101 & 0.059 & 1.70 & 0.099 & 0.060 & 1.645 \\
\hline Substance use total & & & & 0.000 & 0.001 & -0.578 \\
\hline Substance count & & & & 0.014 & 0.012 & 1.157 \\
\hline Overdose: yes-no & & & & -0.028 & 0.033 & -0.827 \\
\hline Combined use: yes-no & & & & -0.026 & 0.033 & -0.767 \\
\hline$R^{2}$ & 0.140 & & & 0.152 & & \\
\hline$F$ for $\Delta R^{2}$ & 0.564 & & & & & \\
\hline
\end{tabular}

ADHD, attention deficit hyperactivity disorder. ${ }^{* * *} p<0.001$.

\begin{tabular}{|c|c|c|c|c|c|c|}
\hline \multirow[t]{2}{*}{ Variable } & \multicolumn{3}{|c|}{ Model 2a } & \multicolumn{3}{|c|}{ Model 2b } \\
\hline & $B$ & SE & $t$ & $B$ & SE & $t$ \\
\hline \multicolumn{7}{|l|}{ ADHD group } \\
\hline Combined-none & 7.82 & 3.68 & $2.12^{*}$ & 5.38 & 3.90 & 1.38 \\
\hline Attention-none & 9.18 & 3.72 & $2.47^{*}$ & 8.12 & 3.77 & $2.15^{*}$ \\
\hline Hyperactivity-none & 11.65 & 5.51 & $2.11^{*}$ & 10.57 & 5.57 & 1.90 \\
\hline Substance use total & & & & 0.014 & 0.118 & 0.121 \\
\hline Substance count & & & & 0.407 & 1.15 & 0.355 \\
\hline Overdose: yes-no & & & & 4.48 & 3.06 & 1.46 \\
\hline Combined use: yes-no & & & & 1.85 & 3.06 & 0.545 \\
\hline$R^{2}$ & 0.055 & & & 0.077 & & \\
\hline$F$ for $\Delta R^{2}$ & 1.02 & & & & & \\
\hline
\end{tabular}

ADHD, attention deficit hyperactivity disorder. ${ }^{*} p<0.05$.
Table 6. Summary of hierarchical regression analysis for variables predicting the sum of positive psychiatric symptoms total (SCL-PST) $(N=180)$
On the basis of the meta-analysis of van Emmeriksevere psychiatric symptoms profile compared to those without ADHD. ADHD was a significant predictor of EuropASI psychiatric status, and able to account for $14 \%$ of its variance. Attention deficit disorder was more strongly associated with mental health problems in SUD clients than hyperactivity disorder. It should be noted that all of the TC clients (even those without ADHD) seemed to show a number of psychiatric symptoms. In our sample, we found no clients without any psychiatric symptoms as measured by SCL-90. Each client showed positive symptoms in at least 3 different areas covered by SCL-90. More than $70 \%$ of the participants reported positive symptoms in all of the 9 areas which were assessed. In our study, the average global severity index (SCL-GSI) was 1.18 , which was approximately double that found in the normal population [38]. van Oortmerssen et al. [13], the prevalence of ADHD in SUD patients was $23.1 \%$, with the stimulant users being predominantly represented by cocaine users. In a more recent and large multicentric study, the prevalence of ADHD in the adult population was even lower (13.9\% out of 1,205 treatment-seeking SUD patients). In our study, the prevalence was twice as high (50.6\%), compared to the average prevalence found in the meta-analysis of van Emmerik-van Oortmerssen et al. [13]. This difference may be attributed to the type of substance, represented in the Czech Republic mainly by methamphetamine. Those with ADHD are more prone to using stimulants [39], and the stimulating effects of self-medicated methamphetamine (e.g., elevated concentration) may have the desired effects on ADHD symptoms [40, $41]$. In addition, this 2 -fold prevalence may also be ex- 
plained by the population of drug users who are treated in TCs. Users with ADHD may encounter problems with the treatment rules in other residential treatment modalities more frequently than those without ADHD. The problems may, for example, be represented by a lower adherence to treatment, and conflicts with treatment staff and other patients, resulting in a higher number of treatment drop-outs. A high prevalence of ADHD in TCs in methamphetamine users was also found in small-scale studies from the Czech Republic (56.6\%) [9] and Japan (55.6\%) [8]. Despite the methodological weaknesses in these 2 studies, their findings were consistent with ours. The importance of our study lies in its methodologically sound and recent prevalence estimates of ADHD in TCs.

In addition to the prevalence of ADHD in the TC population, our TC clients with ADHD experienced frequent and various mental health problems. They also reported a broader and more severe psychiatric symptomatology compared to clients without ADHD. Other studies also showed that adult drug users with ADHD experienced other psychiatric disorders more frequently [42], for example, a prevalence of $10-50 \%$ of anxiety disorder, depressive disorder (15-75\%), broad autism phenotype (6$27 \%)$, oppositional defiant disorder (85\%), behavioral disorder (15-56\%) [43, 44], emotional lability [45], and personality disorders [46]. Barkley and Murphy [43] reported that up to $75 \%$ of those diagnosed with ADHD are predisposed to at least one comorbid disorder. This implies the need for specific therapeutic approaches, individual treatment plans, and the monitoring of the treatment response in clients with ADHD [47]. TCs, which have a more suitable and accepting setup for addressing the specific needs of their clients, may be one of the last alternatives for SUD patients with ADHD and other psychiatric comorbidities $[18,19]$.

The assessment of ADHD in SUD patients always carries the risk of lower accuracy due to acute intoxication, withdrawal syndrome, or the residuals of long-term use. We reported that the participants were screened within the first 10 days of admission. However, all TCs in our study required, according to the national quality treatment standards, the clients to complete an $\sim 3$-week long detoxification unit or other relevant treatment programs. In addition, the clients were screened and observed by the TC staff. There is a very low probability that the clients were intoxicated or experiencing acute withdrawal syndrome at the time of the inquiry. To further minimize the long-term use residuals on ADHD symptomatology, we conducted additional analysis on the differences in
ADHD between participants who reported having abstained from drugs for the past 30 days $(N=92,51.1 \%)$ and participants who reported drug use during the past 30 days $(N=88,48.9 \%)$. We found no significant between-groups differences in ADHD prevalence $\left(\chi^{2}[1]=\right.$ $2.70, p=0.10)$ and the core symptoms of attention or hyperactivity disorder $(p>0.18$, Cohen's $d<0.20)$. However, abstainers reported significantly lower number of hyperactivity symptoms experienced in adulthood $(M=$ 3.97, $\mathrm{SD}=2.96)$, when compared to participants who were using drugs during the past 30 days $(M=4.90, \mathrm{SD}=$ $2.75, t[178]=2.187, p=0.030$, Cohen's $d=0.33$ ). Irrespective of the above, the evidence suggests that the patients may be evaluated for ADHD, even if not yet abstinent [48].

The results of this study indicate the need for a consistent diagnosis of ADHD in TC clients throughout the treatment, to account for possible complications in treatment. Reflecting the high prevalence of ADHD in TC clients, the issue of ADHD represents a challenge for TCs in terms of (1) revisions and modifications of treatment programs in the TC (standard clinical assessment, monitoring of treatment response, and specific training of staff) and (2) the development of specific support components (individualization of treatment and improvement of self-regulation skills in clients) which address the discrepancy between the requirements and which of them this group is able to meet in clinical practice. To facilitate this process, we recommend referring to the international consensus statement on screening, diagnosis, and treatment of patients with comorbid substance use disorders and ADHD [49].

\section{Strengths and Limitations}

The study could be regarded as a solid piece of replication research on ADHD comorbidity in a specialized setting, which corroborates earlier findings of high ADHD prevalence rates among patients with SUDs, in particular among those with a stimulant use disorder. Of the studies analyzing ADHD in the treatment of SUDs, our study was among the first to rigorously study the primarily male clients of TCs who had been diagnosed with methamphetamine use disorder. Another strength of the current study lies in the fact that the Czech Republic is known for the persisting popularity of methamphetamine among drug users [50]. This is due to the history of its use, going back nearly 50 years [51]. It has expectable implications for the spectrum of patients receiving treatment: (1) the majority $(80 \%)$ of Czech problem drug users inject the drug [52]; (2) the treatment settings in TCs allowed us to study 
a population with a generally severe addiction profile, which is, however, not accompanied by serious somatic complications requiring intensive medical attention. Furthermore, the study sample consisted of 180 clients in TCs meeting the national quality treatment standards. Czech TCs share a uniform quality policy and adhere to the Czech Professional Standards and internationally recognized treatment models and methods [24], which results in a high institutional homogeneity in terms of the treatment program and rules. Last but not least, the ADHD assessment was based on DIVA [28], a comprehensive diagnostic method which measured the ADHD symptoms in adulthood and childhood, while most other studies used simple screening tools.

This study also had limitations. The assessment of ADHD in childhood was not confirmed by a person close to the client and, therefore, the recall bias was not completely controlled. However, at least from a psychometrical point of view, the measurement of ADHD was reliable. Despite the fact that the clients of the Czech TCs were predominantly male, the ratio of men in our sample was even higher because the TC which exclusively treats women and mothers with children was one of the 3 TCs which declined to participate. The study would also profit from a proper clinical assessment by a qualified psychiatrist with a full medical record of ADHD diagnosis for every client in our sample. Finally, the superimposition onto female patients would be somewhat problematic as the majority of the sample were men.

\section{Conclusions}

Nearly half of the population of severe, mostly intravenous, male TC clients primarily diagnosed with methamphetamine use disorder, who normally might not be targeted in outpatient research, were screened ADHD positive. ADHD relates to other mental health problems and psychiatric symptoms which may significantly complicate the treatment process. This implies that specific attention should be paid to proper ADHD diagnostic procedures, and the diagnosis of ADHD should be reflected in treatment interventions. In addition to ADHD, attention should also be paid to other psychiatric problems which seem to be frequent in TC clients. Future research should reflect this finding when studying the effectiveness of treatment in TCs. Our findings constitute a significant contribution to the long-lasting debate and criticism of a lack of rigorous clinical studies in TCs [21,23].

\section{Acknowledgement}

The authors would like to thank the teams of the therapeutic communities who participated in the pilot study for their cooperation, which allowed the execution of the research and the creation of this article.

\section{Statement of Ethics}

The study was approved by the Ethics Committee (IORG0002175) of the General University Hospital in Prague (Ref. No. 9/13 GACR; first FM, Charles University; date: April 10, 2013). The informed consent was obtained from patients.

\section{Disclosure Statement}

The authors declare that they have no conflicts of interest to disclose.

\section{Funding Sources}

This study was funded by the project GAČR No. 14-07822S and the institutional financial program PROGRES-P06/LF1/9.

\section{Authors Contribution}

K.L. had full access to all of the data in the study and takes responsibility for the integrity of the data and the accuracy of the data analysis. M.M. and L.Š. were responsible for concept and design. K.L., M.M., R.G., M.Š., and E.R. were involved in acquisition, analysis, or interpretation of data. M.M., K.L., R.G., and E.R. drafted the manuscript. M.M., K.L., and M.Š. were involved in critical re-

\section{References}

1 Daigre C, Roncero C, Grau-López L, Martínez-Luna N, Prat G, Valero S, et al. Attention deficit hyperactivity disorder in cocainedependent adults: a psychiatric comorbidity analysis. Am J Addict. 2013;22(5):466-73.

2 Fayyad J, Graaf RD, Kessler R, Alonso J, Angermeyer $\mathrm{M}$, Demyttenaere $\mathrm{K}$, et al. Cross- national prevalence and correlates of adult attention-deficit hyperactivity disorder. $\mathrm{Br} \mathrm{J}$ Psychiatry. 2007;190(2):402-9.

3 Thomas R, Sanders S, Doust J, Beller E, Glasziou P. Prevalence of attention-deficit/hyperactivity disorder: a systematic review and metaanalysis. Pediatrics. 2015;135(4):e994-1001.
4 van Emmerik-van Oortmerssen K, van de Glind G, van den Brink W, Smit F, Crunelle CL, Swets M, et al. Prevalence of attentiondeficit hyperactivity disorder in substance use disorder patients: a meta-analysis and metaregression analysis. Drug Alcohol Depend. 2012;122(1-2):11-9. 
5 Fiksdal Abel K, Ravndal E, Clausen T, Bramness JG. Attention deficit hyperactivity disorder symptoms are common in patients in opioid maintenance treatment. Eur Addict Res. 2017;23(6):298-305.

6 Silbernagl M, Slamanig R, Stegemann M, Sterzer M, Mayer L, Fischer G, et al. Attention-deficit hyperactivity disorder symptom status in a mixed gender population of opioid-maintained prison inmates. Eur Addict Res. 2019;25(2):80-92.

7 Lugoboni F, Zamboni L, Mantovani E, Cibin M, Tamburin S, Gruppo InterSERT di Collaborazione Scientifica. Association between adult attention deficit/hyperactivity disorder and intravenous misuse of opioid and benzodiazepine in patients under opioid maintenance treatment: a cross-sectional multicentre study. Eur Addict Res. 2020;26(4-5):1-11.

8 Matsumoto T, Kamijo A, Yamaguchi A, Iseki E, Hirayasu Y. Childhood histories of attention-deficit hyperactivity disorders in Japanese methamphetamine and inhalant abusers: preliminary report. Psychiatry Clin Neurosci. 2005;59(1):102-5.

9 Rubášová E, Kalina K, Miovský M, Čablová L, Štastná L. Výskyt ADHD u osob závislých na ilegálních návykových látkách léčených v terapeutických komunitách v Č eské republicepilotní studie. Česká a Slovenská Psychiatrie. 2015;111(5):228-235.

10 Wilson JJ, Levin FR. Attention deficit hyperactivity disorder (ADHD) and substance use disorders. Curr Psychiatry Rep. 2001;3(6): 497-506.

11 Young S, Wells J, Gudjonsson GH. Predictors of offending among prisoners: the role of attention-deficit hyperactivity disorder and substance use. J Psychopharmacol. 2011; 25(11):1524-32.

12 Kalbag AS, Levin FR. Adult ADHD and substance abuse: diagnostic and treatment issues. Subst Use Misuse. 2005;40(13-14): 1955-8.

13 van Emmerik-van Oortmerssen K, van de Glind G, Koeter MWJ, Allsop S, Auriacombe $\mathrm{M}$, Barta C, et al. Psychiatric comorbidity in treatment-seeking substance use disorder patients with and without attention deficit hyperactivity disorder: results of the IASP study. Addiction. 2014;109(2):262-72.

14 Torok M, Darke S, Kaye S. Attention deficit hyperactivity disorder and severity of substance use: the role of comorbid psychopathology. Psychol Addict Behav. 2012;26(4): 974-9.

15 Ferrer M, Andión Ó, Matalí J, Valero S, Navarro JA, Ramos-Quiroga JA, et al. Comorbid attention-deficit/hyperactivity disorder in borderline patients defines an impulsive subtype of borderline personality disorder. J Pers Disord. 2010;24(6):812-22.

16 Paclt I. Hyperkinetická porucha a poruchy chování. Praha, Česká Republika: Grada; 2007.

17 Arias AJ, Gelernter J, Chan G, Weiss RD, Brady KT, Farrer L, et al. Correlates of co-oc- curring ADHD in drug-dependent subjects: prevalence and features of substance dependence and psychiatric disorders. Addict Behav. 2008;33(9):1199-207.

18 De Leon G. Community as method: therapeutic communities for special populations and special settings. Westport, CT: Greenwood Publishing Group; 1997.

19 De Leon G. The therapeutic community: theory, model, and method. New York: Springer Publishing Company; 2000.

20 Vanderplasschen W, Vandevelde S, Broekaert E. Therapeutic communities for treating addictions in Europe: evidence, current practices and future challenges. Luxembourg: Publications Office of the European Union; 2014.

21 Vanderplasschen W, Yates R, Miovský M. Bridging the gap between research and practice in therapeutic communities (TCs) for addictions. J Groups Addict Recovery. 2017; 12(2-3):63-67. https://doi.org/10.1080/1556 035X.2017.1331598.

22 Kalina $K$, Rubášová $E$, Miovský $M$, Čablová L, Štastná L. The effects of ADHD on the process and outcome of drug treatment in therapeutic communities in the Czech Republic: a pilot study. Adiktologie. 2014; 14(3):228-246.

23 De Leon G. Is the therapeutic community an evidence based treatment? What the evidence says. Ther Communities: Int J Ther Support Organizations. 2010;31:104-28.

24 Mravčík V, Chomynová P, Grohmannová K, Janíková B, Tion Leštinová $Z$, Rous $Z$, et et al. Výroční zpráva o stavu ve věcech drog v České republice $\mathrm{v}$ roce 2016 [Annual Report on Drug Situation 2016: Czech Republic]. Praha, Česká Republika: Úřad vlády České Republiky; 2017. https://www.drogy-info.cz/data/ obj_files/32732/786/VZ_2016_drogova_ situace_v_CR.pdf.

25 Mravčík V, Chomynová P, Grohmannová K, Janíková $\mathrm{B}$, Grolmusová L, Tion Leštinová Z, et al. Výroční zpráva o stavu ve věcech drog v České republice v roce 2014 [Annual Report on Drug Situation 2014: Czech Republic]. Praha, Česká Republika: Ưřad vlády České Republiky; 2015. https://www.drogy-info.cz/ data/obj_files/23496/700/VZ_drogy_2014_ fin03_v160202.pdf.

26 Mravčík V, Chomynová $\mathrm{P}$, Grohmannová $\mathrm{K}$, Janíková B, Tion Leštinová Z, Rous Z, et et al. Výroční zpráva o stavu ve věcech drog v České republice v roce 2015 [Annual Report on Drug Situation 2015: Czech Republic]. Praha, Česká Republika: Úřad vlády České Republiky; 2016. https://www.drogyinfo.cz/data/obj_files/32232/780/ VZ_2015_fin_web_vc-opr-tab-3--1_v04. pdf (2016).

27 Miovský M, Čablová L, Kalina K. The effects of ADHD on the course and outcome of addiction treatment in clients of therapeutic communities: research design. Adiktologie. 2014;14(4):392-400.

28 Kooij SJJ, Francken HM. Diagnostic interview for ADHD in adults 2.0 (DIVA 2.0).
Adult ADHD. Diagnostic assessment and treatment. Amsterdam, Netherlands: Pearson Assessment and Information BV; 2010.

29 Kokkevi A, Hartgers C. EuropASI: European adaptation of a multidimensional assessment instrument for drug and alcohol dependence. Eur Addict Res. 1995;1(4):208-10.

30 Derogatis LR. The SCL-90 Manual I: scoring, administration and procedures for the SCL90. Baltimore, MD: Clinical Psychometric Research; 1977.

31 Derogatis LR, Fitzpatrick M. The SCL-90-R, the brief symptom inventory (BSI), and the BSI-18. In: Maruish ME, editor. The use of psychological testing for treatment planning and outcomes assessment: instruments for adults. 3rd ed. Mahwah, NJ: Lawrence Erlbaum Associates Publishers; 2004. vol. 3; p. 1-41.

32 Thylstrup B, Bloomfield K, Hesse M. Incremental predictive validity of the Addiction Severity Index psychiatric composite score in a consecutive cohort of patients in residential treatment for drug use disorders. Addict $\mathrm{Be}$ hav. 2018;76:201-7.

33 Koeter JMW, Hartgers C. Preliminary procedure for the computation of the EuropASI composite scores. Amsterdam, Netherlands: The Amsterdam Institute for Addiction Research; 1997.

34 R Core Team. R: a language and environment for statistical computing. Vienna, Austria: R Foundation for Statistical Computing; 2014. http://www.R-project.org/.

35 Honaker J, King G, Blackwell M. AmeliaII: a program for missing data. J Stat Soft. 2011; 45(7):1-47.

36 Papageorgiou G, Grant SW, Takkenberg JJM, Mokhles MM. Statistical primer: how to deal with missing data in scientific research? Interact Cardiovasc Thorac Surg. 2018;27(2):153-8.

37 Mokhles GL, Bauman S, Card NA. Best practices for missing data management in counseling psychology. J Couns Psychol. 2010; 57(1):1-10.

38 Holi MM, Sammallahti PR, Aalberg VA. A Finnish validation study of the SCL-90. Acta Psychiatr Scand. 1998;97(1):42-6.

39 Lee SS, Humphreys KL, Flory K, Liu R, Glass K. Prospective association of childhood attention-deficit/hyperactivity disorder (ADHD) and substance use and abuse/dependence: a meta-analytic review. Clin Psychol Rev. 2011; 31(3):328-41

40 Minařík J, Gabrhelík R, Malcolm R, Pavlovská A, Miller P. Methylphenidate substitution for methamphetamine addiction and implications for future randomized clinical trials: a unique case series. J Substance Use. 2016; 21(4):435-438. https://doi.org/10.3109/1465 9891.2015.1045047.

41 Wilens TE, Adamson J, Sgambati S, Whitley J, Santry A, Monuteaux MC, et al. Do individuals with ADHD self-medicate with cigarettes and substances of abuse? Results from a controlled family study of ADHD. Am J Addict. 2007;16(Suppl 1):14-3. 
42 Wilens TE. Mechanism of action of agents used in attention-deficit/hyperactivity disorder. J Clin Psychiatry. 2006;67(Suppl 8): 32-8.

43 Barkley RA, Murphy KR. Attention-deficit hyperactivity disorder: a clinical workbook. 3rd ed. New York, NY: Guilford Press; 2006.

44 Abikoff H, McGough J, Vitiello B, McCracken J, Davies M, Walkup J. Sequential pharmacotherapy for children with comorbid attention-deficit/hyperactivity and anxiety disorders. J Am Acad Child Adolesc Psychiatry. 2005;44(5):418-427.

45 Skirrow C, McLoughlin G, Kuntsi J, Asherson $\mathrm{P}$. Behavioral, neurocognitive and treatment overlap between attention-deficit/hyperactivity disorder and mood instability. Expert Rev Neurother. 2009;9(4):489-503.
46 Arias AJ, Gelernter J, Chan G, Correlates of co-occurring ADHD in drug-dependent subjects: prevalence and features of substance dependence and psychiatric disorders. Addict Behav. 2008;33(9):1199-207.

47 Bukstein OG, Roberto A. Moodiness in patients with ADHD and substance use disorders. In: Daviss WB editor. Moodiness in ADHD: a Clinician's guide. Cham: Springer International Publishing; 2018. p. 145-59.

48 van Emmerik-van Oortmerssen K, Vedel E, Kramer FJ. Diagnosing ADHD during active substance use: Feasible or flawed? Drug Alcohol Depend. 2017;180:371-5.

49 van den Brink CL, van den Brink W, Moggi F, International consensus statement on screening, diagnosis and treatment of substance use disorder patients with comorbid attention deficit/hyperactivity disorder. Eur Addict Res. 2018;24(1):43-51.
50 Griffiths P, Mravcik V, Lopez D, Klempová D. Quite a lot of smoke but very limited fire: the use of methamphetamine in Europe. Drug Alcohol Rev. 2008;27(3):236-242.

51 Brenza J, Gabrhelík R. Use of opioid and stimulant medications in the Czech Socialist Republic before the "discovery" of the clandestine manufacturing of locally-specific stimulants and opiates. Adiktologie. 2014;14(3): 284-293.

52 Mravčík V, Chomynová $\mathrm{P}$, Grohmannová $\mathrm{K}$, Janíková B, Černíková T, Rous Z, et al. Výroční zpráva o stavu ve věcech drog v České republice v roce 2017 [Annual Report on Drug Situation 2017: Czech Republic]. Praha, Česká Republika: Úřad vlády České Republiky. 2018. https:// www.drogy-info.cz/data/obj_files/32962/837/ VZdrogy2017_web181207.pdf. 